Manami Hara $\cdot$ Xiaoyu Wang $\cdot$ Veronica P. Paz

Naoko Iwasaki • Masashi Honda • Yasuhiko Iwamoto

Graeme I. Bell

\title{
Identification of three missense mutations in the peroxisome proliferator- activated receptor $\alpha$ gene in Japanese subjects with maturity-onset diabetes of the young
}

Received: January 11, 2001 / Accepted: February 9, 2001

\begin{abstract}
We screened the protein-coding region of the peroxisome proliferator-activated receptor $\alpha$ gene (PPARA) and the flanking intron sequences for mutations in 57 unrelated Japanese subjects with maturity-onset diabetes of the young (MODY). We found three missense mutations, designated P22R, D140Y, and V227A. The D140Y and V227A mutations were found at similar frequencies in MODY and in nondiabetic Japanese subjects, suggesting that they were unlikely to be pathogenic. The P22R mutation was found in a single female subject with MODY. Two of her four siblings, all of whom were diagnosed with diabetes before age 35 years, also inherited the P22R mutation. However, two other diabetic siblings had not inherited the mutant allele, implying that the P22R mutation was not the cause of MODY in this family. Variation in the coding region of PPARA is unlikely to be a major cause of MODY in Japanese people.
\end{abstract}

Key words Diabetes mellitus - Peroxisome proliferatoractivated receptor - PPAR - Missense mutation - Allelic association

\section{Introduction}

The nuclear receptor, peroxisome proliferator-activated receptor $\alpha$ (PPAR $\alpha$, NR1C1; OMIM, 170998) plays a role in the transcriptional regulation of enzymes involved in lipid metabolism in the liver and pancreatic beta cells (Vamecq and Latruffe 1999; Zhou et al. 1998). Reduced expression of

M. Hara $(\bowtie) \cdot$ X. Wang $\cdot$ V.P. Paz $\cdot$ G.I. Bell

Howard Hughes Medical Institute, The University of Chicago, 5841

South Maryland Avenue, MC1028, Chicago, IL 60637, USA

Tel. +1-773-702-9118; Fax +1-773-702-9237

e-mail: mhara@midway.uchicago.edu

$\mathrm{N}$. Iwasaki · Y. Iwamoto

Diabetes Center, Tokyo Women's Medical University, Tokyo, Japan

M. Honda

Shiseikai Daini Hospital, Tokyo, Japan
PPAR $\alpha$ in the beta cell is associated with beta cell dysfunction and lipotoxicity (Zhou et al. 1998). Maturity-onset diabetes of the young (MODY) is a monogenic form of diabetes characterized by autosomal dominant inheritance, early age at onset, and beta cell dysfunction (Fajans and Bell 2000). Mutations in the glycolytic enzyme glucokinase and a series of transcription factors expressed in the beta cell, including hepatocyte nuclear factor (HNF)- $1 \alpha,-\beta$ and $-4 \alpha$, insulin promoter factor (IPF)-1, neurogenic differentiation 1 (NeuroD1), and islet-1 have been associated with MODY (Fajans and Bell 2000; Shimomura et al. 2000). Because MODY appears to be primarily a genetic disorder involving transcription factors expressed in the beta cell, we have been screening the genes encoding various beta cell transcription factors for MODY-associated mutations. PPAR $\alpha$ is both a transcription factor expressed in the beta cell and associated with beta cell dysfunction, and, thus, is a plausible candidate gene. Accordingly, as part of our continuing search for the causes of MODY in Japanese people (Horikawa et al. 2000), we screened the protein-coding region of the peroxisome proliferator-activated receptor $\alpha$ gene (PPARA) for MODY-associated mutations.

\section{Subjects and methods}

Subjects

The MODY group consisted of 57 unrelated Japanese subjects attending the Diabetes Clinic of Tokyo Women's Medical University who were diagnosed with type 2 diabetes before 25 years of age and/or who were members of families in which type 2 diabetes was present in three or more generations. The age at diagnosis (mean $\pm \mathrm{SE}$ ) was $20.1 \pm 7.5$ years; 31 subjects were men and 26 were women; and treatment was insulin $(n=36)$, oral hypoglycemic agents $(n=10)$, and diet $(n=11)$. The clinical features of the MODY group are described more detail by Iwasaki et al. (1997) and Furuta et al. (1997). The control group consisted of 50 unrelated nondiabetic (determined by oral 
Table 1. Sequences of primers used for amplification and sequencing of PPARA

\begin{tabular}{|c|c|c|c|}
\hline Region & Forward primer $\left(5^{\prime}-3^{\prime}\right)$ & Reverse primer $\left(5^{\prime}-3^{\prime}\right)$ & Product size (base pairs) \\
\hline Exon 4 & CAAGTGAACGTTGTTATACG ${ }^{\mathrm{a}}$ & GAGAACAGTTTTCTTGGAGG & 413 \\
\hline Exon 5 & TGGGTGTTCTGAGGTTTATGC & TTATAGGCATGAGATACCGCGC & 365 \\
\hline Exon 6 & $\begin{array}{l}\text { CCATGCCTGGCCTGGAATAAC } \\
\text { AGCTTGATCTGTTCCCTTGGAG }^{a}\end{array}$ & TGGGTGTGAAATGTTGAAGCAC & 394 \\
\hline Exon 7 & $\begin{array}{l}\text { ATGGGTCTGAACTGCCTGTG } \\
\text { CATTCCTGGTTTAAAGTCCTGG }^{\text {a }}\end{array}$ & CCTTAATCGTCCTCTACGAC & 386 \\
\hline Exon 8 & $\begin{array}{l}\text { GGTATCTTGAGTCCTCTGAG } \\
\text { CATTAGTGAGCTGATAGCTGG }^{\mathrm{a}} \\
\text { GCTCAGGCTGGTACTGGATTTC }^{\mathrm{a}}\end{array}$ & TTCCCACCATGTGAGTGTCC & 702 \\
\hline Exon 9 & $\begin{array}{l}\text { CAATATCTAAAGGCAGCTCAG } \\
\text { GGCATGTTTGGTTCCTGAAACTG }^{\text {a }} \\
\text { AGACTCCACCTGCAGAGCAACC }^{a}\end{array}$ & GCCGGTTACCTACAGCTCAG & 605 \\
\hline
\end{tabular}

${ }^{a}$ Denotes primers used for sequencing the polymerase chain reaction (PCR) product

glucose tolerance testing) Japanese subjects. The MODY group has previously been screened for mutations in the hepatocyte nuclear factor (HNF)-1 $\alpha,-1 \beta$ and $-4 \alpha$, IPF-1, NeuroD1/BETA2, NeuroD4, Nkx2.2, HNF-3 $\beta$, HNF-4 $\gamma$, neurogenin 3, and DCoH genes (Horikawa et al. 2000; del Bosque-Plata et al. 2001). Mutations in the HNF-1 $\alpha$ gene have been excluded as the cause of diabetes. However, the MODY group does include one subject with a nonsense mutation in the HNF-1 $\beta$ gene and two subjects with putative diabetes-associated mutations in the HNF- $4 \alpha$ gene. This study was approved by the Institutional Review Board of Tokyo Women's Medical University, and was carried out in accordance with the principles of the Declaration of Helsinki II. Informed consent was obtained from all subjects prior to participation in this study.

\section{Mutation screening}

We screened the protein-coding region of PPARA (exons 4-9) and the flanking introns for mutations by polymerase chain reaction (PCR) amplification and direct sequencing of the PCR products, using an ABI PRISM dRhodamine terminator cycle sequencing ready reaction kit (Applied Biosystems, Foster City, CA, USA) and an ABI model 377 DNA Sequencer. The sequences of the primers used for PCR and sequencing are shown in Table 1 . The presence of each mutation in nondiabetic subjects was determined by amplifying and sequencing the appropriate region of PPARA.

\section{Statistical tests}

Allele frequencies were compared using a $\chi^{2}$ test, and $P<0.05$ was considered significant.

\section{Results}

The PPARA is located on human chromosome 22 (the reference sequence of this chromosome has recently been determined (Dunham et al. 1999)) and spans about $90 \mathrm{~kb}$.
The exon-intron organization of PPARA was determined by sequence analysis of P1-derived artificial chromosome clone 224H4 (Genome Systems, St. Louis, MO, USA) and comparison of genomic and cDNA sequences. This analysis suggested that PPAR $\alpha$ mRNA was encoded by nine exons: the 5 '-untranslated region was encoded by exons 1-3 and part of exon 4; the protein-coding region by exons 4-9; and the $3^{\prime}$-untranslated region by exon 9 . The $5^{\prime}$-rapid analysis of cDNA ends (RACE) of human kidney cDNA revealed clones having a different sequence at their 5 '-end that were derived from an additional exon (designated exon 1A) between exons 1 and 2 . The molecular basis for the heterogeneity in the sequence of the $5^{\prime}$-untranslated region of PPAR $\alpha$ mRNA is not yet determined; i.e., multiple promoters or alternative splicing. The GenBank accession numbers for the PPARA are AL032818, Z94161, and AF270490.

The protein-coding region (exons 4-9) was screened for mutations in the 57 Japanese subjects with MODY. We found three novel missense mutations: P22R, D140Y, and V227A (Table 2). The D140Y and V227A mutations were found in MODY and nondiabetic subjects at similar frequencies, and were, thus, unlikely to be diabetespredisposing mutations. Two of the 57 MODY subjects and 1 of the 50 nondiabetic subjects were heterozygous for the D140Y mutation. The residue Asp140 is located in the putative DNA-binding domain of PPAR $\alpha$. It is conserved in human, mouse, rat, and guinea pig PPAR $\alpha$ and is Glu in the frog sequence. Two of the 57 MODY subjects and 6 of the 50 nondiabetic subjects were heterozygous for the V227A mutation. The residue Val227, which is located in the putative ligand-binding region, is not highly conserved, and this amino acid is Val in human, mouse, and rat $\operatorname{PPAR} \alpha$, Ile in guinea pig, and Ala in frog.

The P22R mutation was found in the heterozygous state in a single MODY subject (subject 91-03; Table 3) and in none of the 50 nondiabetic subjects. The amino acid Pro22 is located in the A/B domain and is conserved among human, rat, mouse, guinea pig, and frog PPAR $\alpha$. It is adjacent to Ser21, which is phosphorylated in response to insulin, leading to an increase in transcriptional activity (JugeAubry et al. 1999). Subject 91-03 was also heterozygous for the V227A mutation. Two siblings (91-04 and 91-06) were 
Table 2. Mutations in PPARA in Japanese

\begin{tabular}{|c|c|c|c|c|c|c|c|}
\hline \multirow[b]{2}{*}{ Location } & \multirow[b]{2}{*}{ Nucleotide $^{a}$} & \multirow{2}{*}{$\begin{array}{l}\text { Nucleotide } \\
\text { change }\end{array}$} & \multirow[b]{2}{*}{ Designation } & \multirow{2}{*}{$\begin{array}{l}\text { Amino acid } \\
\text { change }\end{array}$} & \multirow[b]{2}{*}{ Designation } & \multicolumn{2}{|c|}{$\begin{array}{l}\text { Frequency of major } \\
\text { allele }\end{array}$} \\
\hline & & & & & & MODY & Nondiabetic \\
\hline Codon 22 & 65 & $\mathrm{C}>\mathrm{G}$ & c. $65 \mathrm{C}>\mathrm{G}$ & $\operatorname{Pro}(\mathrm{CCG})>\operatorname{Arg}(\mathrm{CGG})$ & $\mathrm{P} 22 \mathrm{R}$ & C, 0.99 & 1.00 \\
\hline Codon 140 & 418 & $\mathrm{G}>\mathrm{T}$ & c. $418 \mathrm{G}>\mathrm{T}$ & $\operatorname{Asp}($ GAC $)>\operatorname{Tyr}($ TAC $)$ & D140Y & $\mathrm{G}, 0.98$ & 0.99 \\
\hline Codon 227 & 680 & $\mathrm{~T}>\mathrm{C}$ & c. $680 \mathrm{~T}>\mathrm{C}$ & $\mathrm{Val}(\mathrm{GTC})>\mathrm{Ala}(\mathrm{GCC})$ & V227A & $\mathrm{T}, 0.98$ & 0.94 \\
\hline
\end{tabular}

MODY, Maturity-onset diabetes of the young

a Nucleotide (nt) numbering: the A of the ATG of the initiator Met codon is denoted nucleotide +1 , and the lower case "c" for cDNA in front of the nucleotide number indicates that the reference sequence is the cDNA sequence

Table 3. Clinical features of subjects with [P22R; V227A] allele — family 91

\begin{tabular}{|c|c|c|c|c|c|c|c|c|c|c|}
\hline \multirow[b]{2}{*}{ Subject } & \multirow[b]{2}{*}{ Genotype } & \multirow[b]{2}{*}{ Sex } & \multirow{2}{*}{$\begin{array}{l}\text { Age at } \\
\text { Dx (years) }\end{array}$} & \multirow[b]{2}{*}{$\mathrm{Tx}$} & \multicolumn{2}{|c|}{$\operatorname{BMI}\left(\mathrm{kg} / \mathrm{m}^{2}\right)$} & \multicolumn{2}{|c|}{ Cholesterol (mg/dl) } & \multicolumn{2}{|c|}{$\begin{array}{l}\text { Triglycerides } \\
(\mathrm{mg} / \mathrm{dl})\end{array}$} \\
\hline & & & & & Current & Max & Initial & Current & Initial & Current \\
\hline 91-03 & NM & $\mathrm{F}$ & 22 & Ins & 23.2 & 32.8 & 226 & 185 & 165 & 89 \\
\hline 91-04 & NM & $\mathrm{F}$ & 33 & Diet & 28.6 & 32.3 & 222 & 222 & 199 & 322 \\
\hline $91-05$ & NN & M & 33 & Diet & 24.8 & 25.9 & 229 & 206 & 150 & 219 \\
\hline 91-06 & NM & M & 27 & Ins & 20.0 & 30.1 & 135 & 194 & 115 & 142 \\
\hline 91-07 & NN & M & 25 & Ins & 24.2 & 26.0 & 249 & 224 & 242 & 493 \\
\hline
\end{tabular}

N, Normal allele; i.e., [P22; V227]; M, mutant allele [R22; A227]; Dx, diagnosis; Tx, treatment; Ins, insulin; BMI, body mass index

also heterozygous for both the P22R and V227A mutations, and two others (91-05 and 91-07) had not inherited either mutation. The parents were not available for study. These preliminary results suggest that the P22R and V227A mutations may be on the same allele; designated as [P22R; V227A]. Subject 91-03 was diagnosed with diabetes at the age of 22 years and has had diabetes for 20 years (Table 3 ). She is currently being treated with insulin. Four of her siblings (91-04-to-91-07) were also diagnosed with diabetes at an early age, and her youngest sibling has impaired glucose tolerance. The mutant PPARA allele was inherited by only three of five diabetic subjects, suggesting that it was unlikely to be the cause of MODY in this family. The available clinical data (Table 3) provide few clues as to the possible effect of this mutation on phenotype. The three siblings with the mutation had a higher maximum body mass index. There was no apparent association between the mutant allele and fasting total cholesterol or triglyceride levels. The pathophysiological significance of the P22R mutation is unclear.

\section{Discussion}

The present study is the first to screen the PPARA for mutations in patients with MODY. We found two amino acid polymorphisms (D140Y and V227A) and one rare variant (P22R). The present studies do not allow us to ascribe a pathogenic role to any of these mutations. Thus, mutations in PPARA do not appear to be a common cause of MODY in Japanese people. Recent studies also suggest that this gene does not have a major role in the development of type 2 diabetes (Lacquemant et al. 2000).
Acknowledgments This work was supported by the Howard Hughes Medical Institute, the Blum-Kovler Foundation, and grants from the United States Public Health Service (DK-20595 and DK-44840); the Japanese Ministry of Health and Welfare (for Research on the Human Genome and Gene Therapy); and the Japanese Ministry of Science, Culture, and Sport (10671084).

\section{References}

del Bosque-Plata L, Lin J, Horikawa Y, Schwarz PEH, Cox NJ, Iwasaki N, Ogata M, Iwamoto Y, German MS, Bell GI (2001) Mutations in the coding region of the neurogenin 3 gene (NEUROG3) are not a common cause of maturity-onset diabetes of the young in Japanese subjects. Diabetes 50:(in press)

Dunham I, Shimizu N, Roe BA (1999) The DNA sequence of human chromosome 22. Nature 402:489-496

Fajans SS, Bell GI (2000) Maturity-onset diabetes of the young: a model for genetic studies of diabetes mellitus. In: LeRoith D, Taylor SI, Olefsky JM (eds) Diabetes mellitus: a fundamental and clinical text, 2nd edn. J.P. Lippincott, Philadelphia, pp 691-705

Furuta H, Iwasaki N, Oda N, Hinokio Y, Horikawa Y, Yamagata K, Yano N, Sugahiro J, Ogata M, Ohgawara H, Omori Y, Iwamoto Y, Bell GI (1997) Organization and partial sequence of the hepatocyte nuclear factor-4 $\alpha$ /MODY1 gene and identification of a missense mutation, R127W, in a Japanese family with MODY. Diabetes 46:1652-1657

Horikawa Yo, Horikawa Yu, Cox NJ, Iwasaki N, Ogata M, Iwamoto Y, Schwitzgebel V, German MS, Bell GI (2000) $\beta$-Cell transcription factors and diabetes: no evidence for diabetes-associated mutations in the gene encoding the basic helix-loop-helix transcription factor neurogenic differentiation 4 (NEUROD4) in Japanese patients with MODY. Diabetes 49:1955-1957

Iwasaki N, Oda N, Ogata M, Hara M, Hinokio Y, Oda Y, Yamagata K, Kanematsu S, Ohgawara H, Omori Y, Bell GI (1997) Mutations in the hepatocyte nuclear factor-1 $\alpha /$ MODY3 gene in Japanese subjects with early- and late-onset NIDDM. Diabetes 46:1504-1508

Juge-Aubry CE, Hammar E, Siegrist-Kaiser C, Pernin A, Takeshita A, Chin WW, Burger AG, Meier CA (1999) Regulation of the transcriptional activity of the peroxisome proliferator-activated receptor 
$\alpha$ by phosphorylation of a ligand-independent trans-activating domain. J Biol Chem 274:10505-10510

Lacquemant C, Lepretre F, Pineda Torra I, Manraj M, Charpentier G, Ruiz J, Staels B, Froguel P (2000) Mutation screening of the PPAR gene in type 2 diabetes associated with coronary heart disease. Diabetes Metab 26:393-401

Shimomura H, Sanke T, Hanabusa T, Tsunoda K, Furuta H, Nanjo K (2000) Nonsense mutation of islet-1 gene (Q310X) found in type 2 diabetic patient with a strong family history. Diabetes 49:15971600

Vamecq J, Latruffe N (1999) Medical significance of peroxisome proliferator-activated receptors. Lancet 354:141-148

Zhou Y-T, Shimabukuro M, Wang M-Y, Lee Y, Higa M, Milburn JL, Newgard CB, Unger RH (1998) Role of peroxisome proliferatoractivated receptor $\alpha$ in disease of pancreatic $\beta$ cells. Proc Natl Acad Sci USA 95:8898-8903 